\title{
FACTORS ASSOCIATED WITH THE USE OF COSMETIC HORMONES AMONG TRANSGENDERS IN YOGYAKARTA, INDONESIA
}

\author{
Destinady Kadiser Miden'), Hanung Prasetya'²), Bhisma Murti1) \\ ${ }^{1)}$ Masters Program in Public Health, Universitas Sebelas Maret \\ ${ }^{2}$ School of Health Polytechnics, Ministry of Health Surakarta
}

\begin{abstract}
Background: Gender-affirming surgeries and hormone therapy are medically necessary treatments to alleviate gender dysphoria. However, studies into factors determining decision to use hormonal and cosmetic treatment among transgender in Indonesia are scarce. This study aimed to determine factors associated with the use of cosmetic hormones among transgenders in Yogyakarta, Indonesia, using Theory of Planned Behavior (TPB).

Subjects and Method: This was a cross-sectional study carried out in Yogyakarta, Indonesia, in November 2018. A sample of 201 transgender was selected by snowball sampling and fixed disease sampling. The dependent variable was the use of cosmetic hormones. The independent variables were age, intention, attitude, perceived behavioral control. The data were collected by questionnaire and analyzed by a multiple logistic regression.

Results: The use of cosmetic hormones increased with age $(b=0.75 ; 95 \% \mathrm{CI}=0.16$ to 1.48 ; $\mathrm{p}=0.045)$, strong intention $(\mathrm{b}=1.61 ; 95 \% \mathrm{CI}=0.94$ to $2.28 ; \mathrm{p}<0.001)$, positive attitude $(\mathrm{b}=$ 1.30; $95 \% \mathrm{CI}=0.60$ to $1.99 ; \mathrm{p}<0.001)$, and strong perceived behavior control $(\mathrm{b}=-1.04 ; 95 \%$ $\mathrm{CI}=-1.72$ to $-0.35 ; \mathrm{p}=0.003)$. Adjusted $\mathrm{R}^{2}=23 \%$.

Conclusion: The use of cosmetic hormones is directly increased with age, intention, attitude, and perceived behavior control. Theory of Planned Behavior can be used to explain the use of cosmetic hormones among transgender.
\end{abstract}

Keywords: cosmetic hormones use, transgender

\section{Correspondence:}

Destinady Kadiser Miden. Masters Program in Public Health, Universitas Sebelas Maret. Jl. Ir. Sutami 36 A, Surakarta 57126, Cnetral Java, Indonesia.

Email: destinady.kmiden@gmail.com. Mobile: 085328999232

The $5^{\text {th }}$ International Conference on Public Health

Best Western Premier Hotel, Solo, Indonesia, February 13-14, 2019 | 157 https://doi.org/10.26911/theicph.2019.02.02 